\title{
A PÉNZÜGYI KULTÚRA AZ EURÓPAI OKTATÁSBAN
}

Kovács Levente - Pásztor Szabolcs

\begin{abstract}
ABSZTRAKT
Jelen tanulmány elsőként arra kíván rávilágítani, hogy a világ más régióival való összevetésben milyen helyzetben van az európai pénzügyi kultúra, és az egyes európai uniós országok milyen jellegü programokat indítanak/indítottak a kultúra javítása érdekében. Feltárjuk, hogy milyen kapcsolat van a fejlettség legáltalánosabb mutatója és a pénzügyi kultúra között, valamint rámutatunk arra, hogy a pénzügyi műveltség fokozatos emelésével további növekedési potenciál azonosítható. Megvizsgáljuk, hogy egyes európai országok gyakorlatát megismerve, a jó gyakorlatok hogyan alkalmazhatók máshol. Mindennek azért is van komoly jelentősége, mert az új típusú koronavírus-járvány és a folyamatosan zajló digitalizáció újabb kihívások elé állította a pénzügyi műveltség fejlesztésén dolgozó szakembereket, akiknek az új kihívások ellenére is fel kell hívniuk a figyelmet a pénzügyi kultúra fontosságára. Öt európai ország összehasonlításával láthatóvá válik, hogy a komplex, számos szereplőt magukban foglaló programok a legeredményesebbek, de ezeken túl szükséges lenne a pénzügy kultúrát érintő tantárgyak oktatásának kötelezővé tétele.
\end{abstract}

JEL-kódok: A20, G53,

Kulcsszavak: pénzügyi oktatás, európai országok, programok, kezdeményezések

\section{BEVEZETÉS}

Különösen a harmadik évezred elején kapott nagy jelentőséget az a tény, hogy szükséges az egyén figyelmét minél inkább felhívni a pénzügyi tudatosság legalapvetőbb kérdéseire, és ezek között leginkább a különböző megtakarítási formákra. Ehhez igazi lökést a 2007-2009-es pénzügyi, majd reálgazdasági válság adott, ugyanis ekkor a közgazdászok pénzügyi kultúrát érintő, modern felfogása különösen a figyelem középpontjába került. A világ és az európai kontinens kormányai sorra indították el, illetve erősítették meg a pénzügyi kultúrát érintő

1 Kovács Levente fötitkár, Magyar Bankszövetség, egyetemi tanár, Miskolci Egyetem. E-mail: kovacs.levente@bankszovetseg.hu.

PásztorSzabolcs docens, Nemzeti Közszolgálati Egyetem. E-mail: pasztor.szabolcs@uni-nke.hu. 
programjaikat, és igyekeztek minél szélesebb tömegek számára elérhetővé tenni a releváns oktatási és képzési anyagaikat. Mindezt tették annak érdekében, hogy a társadalmi csoportok sérülékenységét csökkentsék, illetve időközben az is nyilvánvalóvá vált, hogy egyértelmü és szoros kapcsolat van a pénzügyi kulturáltság szintje és a gazdasági növekedés között (Kovács-Nagy, 2022). Alapvetően a pénzügyi oktatás területén a harmadik évezred elején markáns változások következtek be, amelyek áttekintése és értékelése időről időre szükségszerü és tanulságos.

A tanulmány elsődleges célja, hogy röviden bemutassa a világ néhány régiójának teljesítményét a pénzügyi kultúra területén, hogy jobban megértsük Európa és az európai országok jellemző jegyeit. Emellett pedig érdemes azt is áttekinteni, hogy a vizsgálat alá vont öt országban (Finnország, Németország, Franciaország, Hollandia, Svájc) milyen pénzügyi tudatosságot javítani kívánó programok futnak, és ezek milyen mértékben tudnak hozzájárulni a pénzügyi müveltség javulásához. Az összehasonlításban és az értékelésben nagy segítségünkre lehet az a tény, hogy a Gazdasági Együttmüködési és Fejlesztési Szervezet (Organization for Economic Cooperation and Development, OECD) által elindított Financial Literacy Programme elindulása óta jelentősen megszaporodott a releváns szakirodalmak száma, és ezek segítségével érdemes lehet áttekinteni azt, hogy milyen pénzügyi kulturáltsági szinten vannak egyes európai országok. Emellett pedig számba lehet venni azt is, hogy milyen célzottan a pénzügyi tudatosság és tájékozottság általános szintjét emelni kívánó programok és kezdeményezések indultak el ezekben az országokban.

A tanulmány tehát az említett államok jelenlegi helyzetét árnyalja, és a pénzügyi kulturáltság terén meghozott erőfeszítéseket tárgyalja. Az egyes országok példája és eredményei sokatmondóak lehetnek a hazai döntéshozók számára is, azonban azt már elöljáróban is leszögezhetjük, hogy gyakran még a gazdaságilag legfejlettebb országokban is vannak hiányosságok a pénzügyi műveltség területén. Általános probléma továbbá, hogy a pénzügyi képzettség mind társadalmi csoportokon, mind pedig országokon belül is nagy szórást mutat, az országok közötti különbségeket már nem is említve. Ez a probléma nagy valószínűséggel enyhíthetö lenne a pénzügyi oktatás kötelezővé tételével.

A tanulmány logikai menete a következő: elöször a világ és az európai országok pénzügyi kulturális helyzetét igyekszünk bemutatni, és megvilágítjuk, hogy hol tartanak az egyes régiók és országok. Ezt követően a pénzügyi műveltség és a gazdasági növekedés kapcsolatát tárjuk fel, majd később az egyes országok gyakorlatait emeljük ki. A következtetések pedig lehetőséget adnak arra, hogy a jó gyakorlatokat mérlegelés tárgyává tegyük, és esetlegesen implementáljuk. 


\section{A PÉNZÜGYI KULTÚRA HELYZETE A VILÁGBAN ÉS EURÓPÁBAN}

A Standard \& Poor's pénzügyi ismeretekkel foglalkozó és folyamatosan megismételt globális felmérése 140 országot érint; jellemzően 150 ezer felnőttet keresnek meg négy sztenderd kérdéssel, amelyek a kamatos kamatot, az inflációt, a kockázatok megosztását és az egyszerű kamatszámítást érintik (Klapper et al., 2015). Azokat, akik e négy kérdés közül legalább háromra helyesen válaszolnak, már pénzügyileg müveltnek tekinthetjük (1. táblázat). A felmérésekből historikusan is megállapítható, hogy a világátlagban a Standard \& Poor's csak minden harmadik felnőttet tud pénzügyileg tájékozottnak tekinteni. Az Európai Unió, az USA és az Európán kívüli fejlett országok átlagosan magasabb pontszámot érnek el, mint az ezen kívül eső országok, de minden egyes régión belül vannak kimondottan jól és rosszul teljesítő szereplők. Botswanában, Bhutánban, Türkmenisztánban, vagy éppen Uruguayban szinte minden második ember rendelkezik pénzügyi ismeretekkel, a pénzügyi műveltség aránya azonban 20 százalék alatti Haitin, Nepálban, Tádzsikisztánban vagy éppen Szomáliában. A rendszer jellemzője tehát a nagyfokú heterogenitás.

\section{1. táblázat}

Pénzügyi tudatosság a világban

\begin{tabular}{ccc}
\hline Ország/régió & Országok száma & Elért pontszám \\
\hline EU & 28 & 50 \\
EU-n kívüli fejlett (USA kivételével) & 8 & 58 \\
USA & 1 & 57 \\
Kína & 1 & 28 \\
Ázsia (Kína kivételével) & 12 & 32 \\
Afrika & 35 & 33 \\
FÁK-térség & 12 & 30 \\
Latin-Amerika és a Karib-térség & 19 & 29 \\
\hline
\end{tabular}

Forrás: Batsaikhan-Demertzis (2018)

A felmérések eredményei fontos kapcsolatokra és tényezőkre tapintanak rá, melyek között elemi fontosságú azt megemlíteni, hogy az egy före jutó GDP-vel közelített gazdasági fejlettség és a pénzügyi kultúra között egyértelmü összefüggés van, azonban ez az együttmozgás a már fejlett gazdaságok esetében markánsabb, mint a fejlődő és feltörekvő országokban. A Standard \& Poor’s felméréseiből jól látható továbbá az is, hogy a pénzügyi ismeretek, a számtani ismeretektől eltérő- 
en, a „gazdag” országok készsége. (Amíg kimondottan jók a matematikai adottságok az olyan fejlődő és feltörekvő országokban, mint India vagy Kína, addig a pénzügyi müveltségük terén van még növekedési tartalékuk.) Amíg azonban viszonylag erős kapcsolat van az egy före jutó GDP és a pénzügyi kultúra pontszámai között a fejlett országok esetében, az alsó 50 százaléknál viszont kevésbé egyértelmű a gazdasági fejlettséggel együttmozgás (Batsaikhan-Demertzis, 2018).

Kimutatható, hogy a pénzügyi ismeretek a fejlettség magasabb szintjén válnak egyre fontosabbá. Mindez ellentétben áll azzal az általános szintű oktatással, amely a fejlettség minden szintjén releváns és a GDP-vel egyértelmü pozitív kapcsolatot mutat (1. ábra).

\section{1. ábra}

\section{Az általános és a pénzügyi oktatás kapcsolata az egy főre eső GDP-vel}
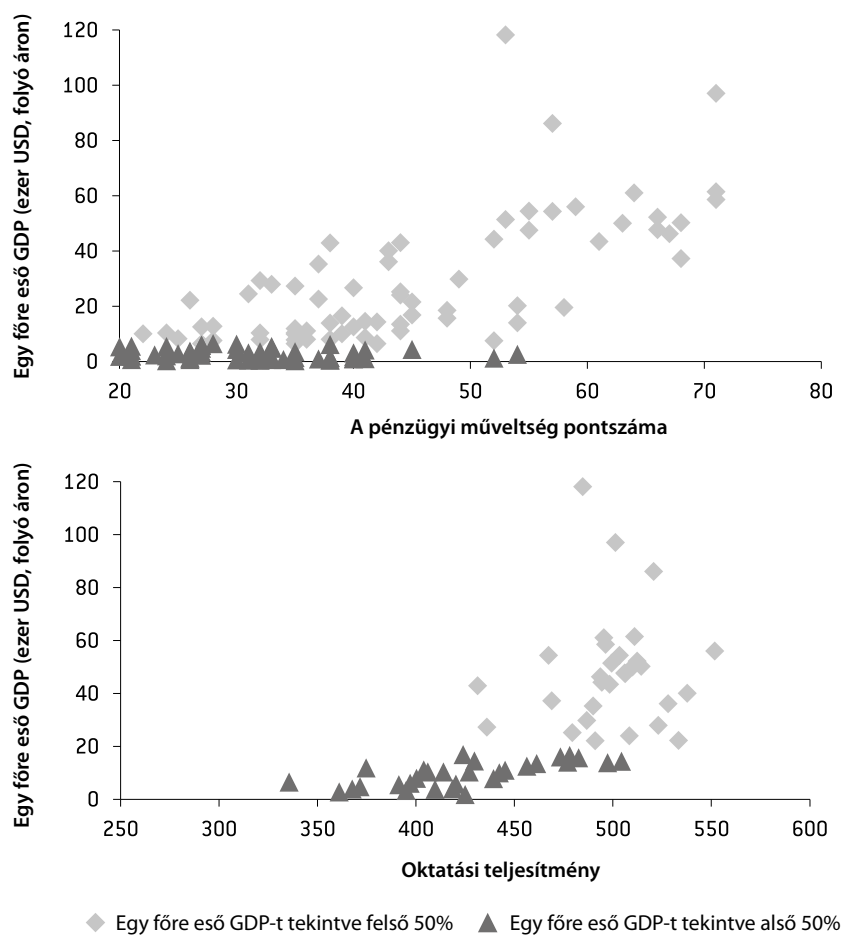

Forrás: Batsaikhan-Demertzis (2018)

A fö üzenet természetesen nem az, hogy a szerényebb fejlettségü országokban nincs szükség a pénzügyi tudatosság emelésére, hanem sokkal inkább arról van szó, hogy szerényebb a megtérülés foka. Több kutatás is bizonyítja, hogy az oktatás 
általános színvonalának emelése megágyaz a későbbi pénzügyi oktatás eredményességének. Ebből pedig az következik, hogy amíg az Európán kívüli jellemzően fejletlenebb régióknak egy következetes forgatókönyv mentén kell elökészíteniük a pénzügyi kultúra fejlesztését, és ez jellemzően egy hosszabb folyamat, addig Európában már célzott programokkal érdemes előremozdítani a pénzügyi kultúrát.

Az Európai Unió pénzügyi tudatosságot taglaló kutatási eredményei nagyságrendileg nem térnek el az USA hasonló mutatóitól. Fontos azonban azt kiemelni, hogy a teljes mutató mögött számos hasonlóság azonosítható: az alacsonyabb jövedelmi csoportokba tartozók, a nők és a kevésbé képzett válaszadók alacsonyabb pontszámokat érnek el, mint a népesség egyéb része. A pénzügyi tudatosságot mérő mutató a korcsoportok között púp alakú eloszlást mutat. A 25 év alattiak és a 70 év felettiek érik el a legalacsonyabb mutatókat, és a legtöbb jó válasz az 55-65 év közötti korcsoportban születik (Lusardi-Mitchell, 2011). A nők általában minden országban és minden korcsoportban alacsonyabb pontot érnek el, és sokkal gyakrabban válaszolnak nem tudommal, mint a férfiak. Ezzel ellentétben nincs nemek közötti különbség az iskoláskorúak pénzügyi tudatossága esetében, amely megerősíti a fiatalkorban történő pénzügyi oktatás szükségességét (OECD, 2012). Ezen a ponton érdemes feltennünk viszont azt a kérdést, hogy miért is annyira kiemelten fontos a pénzügyi kultúra az inkluzív növekedés szempontjából. Erről Kovács-Nagy (2022) úgy vélekedik, hogy a pénzügyi tudás megszerzésének támogatása, az esélyegyenlőség megteremtésének eszköze is. Ezen túl a következőkben áttekintjük azt, hogy az európai környezetben milyen lényeges elemek említhetők.

\section{A PÉNZÜGYI KULTÚRA ÉS AZ INKLUZÍV NÖVEKEDÉS KAPCSOLATA EURÓPAI KONTEXTUSBAN}

A releváns szakirodalom tanulmányozásakor egyértelműnek tűnik, hogy az inkluzív növekedés elérésének egyik előfeltétele az, ha felvértezzük az embereket azon képességekkel, amelyekkel jobban el tudnak igazodni az egyre összetettebb pénzügyi világban. A szegény és hátrányos helyzetű társadalmi rétegek számára a növekvő pénzügyi tudatosság egyértelműen nagyobb hozzáférést jelent a gazdasági növekedés előnyeinek kiaknázásához (Batsaikhan-Demertzis, 2018).

Ahogyan azt korábban is hangsúlyoztuk, a különböző pénzügyi műveltséget mérő kutatásokban a kevésbé képzett és alacsonyabb jövedelmű egyének alacsonyabb pontszámot érnek el, mint a népesség többi része. Ráadásul nemenkénti és regionális eltérések is azonosíthatóak, utóbbiak esetében pedig az látható, hogy a vidéken élők rendre alacsonyabb pontszámot érnek el, mint a városban élők. Az USA-ban ebben az értelemben létezik még egy bizonyosfajta faji szegregáció, 
ugyanis a fehérek és az ázsiai származásúak rendszeresen jobban teljesítenek a pénzügyi tudatosságot feszegető kutatásokban, mint a feketék és a spanyol ajkúak. Európában pedig a bevándorló hátterű iskolás korú gyermekek rendszeresen alulteljesítenek a nem bevándorló hátterüekkel szemben. Az inkluzív növekedés legfontosabb hívószavai a szegénység, a társadalmi kirekesztettség, az egyenlőtlenség és a társadalmi mobilitás, így ezen tényezők fényében árnyaljuk tovább a pénzügyi kultúra és a gazdasági növekedés európai kontextusát.

Egyértelmű és statisztikailag kimutatható kapcsolat tárható fel az egyenlőtlenség és a pénzügyi tudatosság mutatói között az európai uniós országokban. A reláció egyértelmű: azon országok esetében, ahol jobbak a pénzügyi tudatosságot mérő mutatók, jellemzően alacsonyabb a vagyoni és jövedelmi koncentráció foka (Batsaikhan-Demertzis, 2018). Ebbe a kategóriába tartozik Svédország, Dánia, Hollandia vagy éppen Finnország. Alacsonyabb mutatókhoz pedig nagyobb egyenlőtlenség társul: Románia, Portugália, Bulgária, Ciprus. A kapcsolat tehát egyértelmüen negatív a két vizsgált tényező között. Lusardi és szerzőtársai (2017) tanulmányukban azt bizonyították, hogy a pénzügyi műveltség a jövedelmi egyenlőtlenségek 30-40\%-át magyarázza. Phelps (2017) munkájában pedig arra irányította rá a figyelmet, hogy a magasabb pénzügyi műveltség egyértelmüen növekedést generáló tényező. Mindezek tükrében az európai országok felismerték a pénzügy kultúra terjesztésében rejlő lehetőségeket, különböző programok és kezdeményezések mentén megpróbálják kiaknázni annak növekedésgeneráló hatásait.

\section{KÖRKÉP A PÉNZÜGYI KULTÚRA TERJESZTÉSÉNEK MEGJELENÉSI FORMÁIRÓL}

Az Európai Bankszövetség (European Banking Federation) 2020 novemberi jelentésében megállapította, hogy összesen 35 európai ország vesz részt az európai pénzügyi műveltségi mozgalomban, és mintegy 125 külön kezdeményezés létezik, amelyekkel egész Európában a pénzügyi oktatást kívánják népszerüsíteni és a pénzügyi tudatosságot erősíteni. A részt vevő országok egyre inkább arra törekednek, hogy összekapcsolják a köz-, illetve a magánszférát a kérdéskör fontosságának minél jobb kiemelése érdekében (EBF, 2020).

Eddig kimondottan látványos kezdeményezések születtek, hiszen többek között a nemzeti bankszövetségek igyekeznek önállóan vagy társult formában európai programokat indítani. A leggyakrabban a tanárok, az iskolások és többek között a nyugdíjasok csoportjait online forrásokkal és szórólapokkal célozzák meg, de ezen kívül komolyabb figyelemfelkeltő kezdeményezések is vannak. Ezek nem nélkülözik az online és applikációs megoldásokat sem, amelyekkel a tanulásra 
legfogékonyabbakat igyekeznek minden lehetséges módszerrel megcélozni. A következőkben öt ország példáját szemlélteti a tanulmány.

\subsection{Finnország példája}

Finnország kapcsán elsőként arra érdemes rámutatni, hogy alapvetően kötelező a pénzügyi oktatás, azonban az ismeretek átadása más tantárgyakba van integrálva. Korábban a finn jegybank a pénzügyi oktatásra vonatkozóan nemzeti stratégiát dolgozott ki, azonban ennek implementálására még nem került sor. Emellett azonban kimondottan perspektivikus és látványos a magán- és az állami szereplők együttmüködése. Ennek eredményeként olyan programok jöttek létre, mint az Economic Guru (Talousguru) vagy éppen a Zaldo (EBF, 2020).

A Finance Finland (Finanssiala, FFI) kezdeményezés szerint minden finn számára elemi fontosságú a személyes pénzügyek hatékony menedzselése. Az FFI igyekszik egy ernyő alá vonni a pénzügyi szektort, ebbe pedig beleértendő a bankokon kívül a biztosítók, a brókerek és az alapkezelők köre is. Minden egyes évben nagyjából 25 ezer finn részesül az FFI-hez köthető pénzügyi oktatásban. A pénzügyi műveltség elsajátítása kötelező, ugyanis az általános iskolákban a társadalmi tanulmányok, a háztartási gazdaságtan és a matematikai tantárgyak keretein belül történik a személyes pénzügyek oktatása. Az oktatási anyagot és a képzési programot a tanulók 18 éves koráig az állam bocsátja rendelkezésre. A célkitűzés egyértelmü: fel kell készíteni az egyént arra, hogy saját maga tudja kezelni a pénzügyeit és a kockázatait.

Ahogyan azt korábban is kiemeltük, a szervezet által elindított két legfontosabb program az Economic Guru és a Zaldo. A Zaldo egy innovatív, játékos tanulási környezetet nyújt, amely a 10-16 éves diákokat célozza meg. A játék vizsgalehetőséget is biztosít, amelynek a győztesei Finnország képviselöiként indulhatnak el az European Money Quiz döntőjében. Az Economic Guru a középiskola felső tagozatosai számára létrehozott éves verseny, mely 1997-ben indult és azért is egyedülálló, mert a jól teljesítők a finn egyetemek közgazdasági programjaira felvételi vizsga nélkül nyerhetnek felvételt. Az országban nagyjából 1000 diák vesz részt a versenyen minden évben. Érdekesség, hogy a versenysorozatot a kilencvenes évek elején megélt recessziós tapasztalatok és a finnek általános pénzügyi müveltségével kapcsolatos széles körü aggodalma indította el.

A Getting to know the economy egy olyan szemináriumi sorozat, amely azokat a társadalomtudományi területen mozgó tanárokat célozza meg, akik pénzügyi ismeretek oktatásával foglalkoznak. A programban több mint 300 tanár vesz részt. Az FFI ezen túl 2019-ben 100, 2020-ban pedig 50 biztosításhoz kapcsolódó rendezvényt tartott, amelyekkel nagyjából 2200 finn fiatalt értek el. Ezen programok 
célja a magán- és az állami biztosítási rendszerek megismerése volt. A jelzett intézményen túl a finn bankoknak saját kezdeményezései is vannak, amelyek kapcsolódnak egyéb szereplökhöz is (Junior Achievement Finland és Economy and Youth). Néhány bank komoly programsorozatot hozott létre, és látványosan növelte a rendelkezésre álló forrásokat is. 2020 óta a Bank of Finland a pénzügyi oktatásért felelős nemzeti entitás, emellett pedig ez az intézmény őrködik a nemzeti stratégia alakítása felett is. A Ministry of Education és a Finnish National Agency for Education felelős az iskolákban történő pénzügyi oktatásért (EBF, 2020).

\subsection{Németország példája}

Németországban a 16 szövetségi tartományból háromban kötelező a pénzügyi oktatás, és a nemzeti bankszövetség számos sikeres projektet jegyez. Egyelöre nincs nemzeti szintü stratégia, és a pénzügyi oktatás decentralizált. Az országban szinte alapvetés, hogy az iskolákban a diákok nem kapnak kellő pénzügyi oktatást. Emellett pedig nem kielégítő a színvonal sem, ezért kiemelt fontosságúak a különböző kezdeményezések. Németországban nagyjából 25 éve a Német Bankszövetség (Association of German Banks, AGB) felelős a pénzügyi müveltség javításáért. Alapvetően a szervezet két legfontosabb programja két iskolai verseny; a School banker és a Youth and Economy. Az elöbbit 1999-ben vezették be: alapvetően egy kimunkált üzleti játék a felső tagozatos diákok számára. A résztvevők kisebb csoportokban igyekeznek a saját virtuális bankjukat különböző piacokon menedzselni. Abban kell dönteniük, hogy milyenek legyenek a kölcsönök kamatai, kötvényeket kell kibocsátaniuk, fiókokat kell nyitniuk vagy éppen bezárniuk és meg kell határozniuk a marketingköltségeket is. Három hónapon keresztül minden csoport (egyébiránt fordulónként 800) 20 piacon játszik. Minden év márciusában a legjobb 20 csapat egymás ellen játszik Berlinben. A győzteseknek pedig egyéni, illetve az iskoláik számára odaítélt díjakat kapnak. A verseny egyszerre nyújt betekintést a diákoknak a vállalkozások és a bankok működésébe, miközben teszteli csapatmunkájukat, kezdeményezőkészségüket, elemző gondolkodásukat és kommunikációs készségeiket is (EBF, 2020).

A 200o-ben megszületett Youth and Economy kezdeményezést a Német Bankszövetség és a Frankfurter Allgemeine Zeitung koordinálja. Nagyjából 1000 középiskolás diák kapja meg naponta a napilapot, és megtanulják, hogyan kell értőn elolvasni az újság gazdasági hasábjait. Ezt követően azokról a vállalatokról írnak a diákok, amelyek többször megjelentek az újságban. Ezután pedig minden hónapban és negyedévben a diákok cikkei helyet kapnak a lap nyomtatott változatában. Majd pedig minden szeptemberben a legjobb három diák és azok iskolái értékes díjakat kapnak a Német Bankszövetség elnökétől, a Frankfurter Allgemeine Zeitung főszerkesztőjétől, valamint valamelyik szövetségi minisztertől, esetleg a 
kancellártól (EBF, 2020). Az elkötelezett tanároknak köszönhetően mindegyik verseny sikeres volt az utóbbi 20 évben. Több mint 105 ezer diák vett részt a vetélkedőkön Németországból, Ausztriából és Svájcból. Ezenkívül a Német Bankszövetség még más kezdeményezéseket is ajánlott, ezeket pedig számos tantárgyba lehet integrálni (társadalom- és politikatudományok, német nyelv és matematika) az általános iskolától kezdődően egészen a gimnáziumokig. Ennél fogva azok a diákok, akik nem részesülnek pénzügyi oktatásban, vagy nem tanulnak közgazdasági tárgyakat a tanterveik részeként, megtanulhatják, hogyan bánjanak okosan a pénzükkel.

Ezen túl a Német Bankszövetség koordinálja az ország részvételét a European Money Quiz programban is. A szervezet által gondozott This is Money egy olyan program, amely a tanárokat célozza meg oktatási anyagokkal (leginkább prezentációkkal). Az ehhez hasonló Money at School ugyancsak a tanárokat segíti magyarázó videókkal, podcastokkal és interaktív okos megoldásokkal. Az ehhez kapcsolódó applikációt 2019-ben 30 ezerszer töltötték le, és megkapta a Comenius Edu Media kitüntetést is. Az All around money egy olyan szerepjáték, amelyben a diákoknak azt kell kitalálniuk, hogy milyen pénzügyi személyiséggel rendelkeznek, és játékosan megismerkednek a legfontosabb pénzügyi kérdésekkel. A Get Ready egy olyan program, amelynek a segítségével a diákok arról kaphatnak képet, hogy szakmai szempontból mivel szeretnének foglalkozni a jövőben.

A Német Bankszövetségnek az egyik legfontosabb partnere a nemzeti szabályozó hatóság, a Német Szövetségi Bank, amely egyébiránt a közelmúltban hozta létre a pénz tematikájú múzeumát Frankfurtban. Az országban számos olyan kezdeményezés van, amely a pénzügyi oktatást és a vállalkozások indítását célozza meg, azonban ezek többsége kis horderejü, és regionálisan működik. Éppen emiatt hozta létre a Federal Ministry of Economics a Spirit of Entrepreneurship nevü hálózatot, amelynek célja a kezdeményezések összefogása. A német bankszövetség támogatja továbbá a Germany - Land and Ideas kezdeményezést, amely pénzügyi tudatossági programokat indít, egyben implementál is. A német bankszövetség szoros együttmüködésben dolgozik azzal a 170 bankkal, amelyet képvisel. A nagy bankok közül a Deutsche Bank, a Commerzbank és a Hypo-Vereinsbank saját pénzügyi oktatási programot is gondoz. Érdekesség, hogy Németországban a fogyasztóvédelmi csoportok részéről erős ellenállás tapasztalható a bankok pénzügyi tudatosságot érintő kampányai kapcsán. A banki szektor azonban széles támogatást élvez az oktatási programjai révén. 


\subsection{Franciaország példája}

Összességében a franciák érdeklődnek a gazdaság és a gazdasági kérdések iránt, azonban egészen keveset tudnak ezekről. A pénzügyi tudatosságuk pedig nagyjából az egyéb más európai országokéhoz hasonlítható (Arrondel, 2018). Sok válaszadónak van gondja az olyan alapvető pénzügyi fogalmakkal, mint a kockázatok diverzifikációja, infláció vagy éppen kamatos kamat. A megkérdezettek nagyjából 48 százaléka tudott a kamatokhoz kapcsolódóan jó válaszokat adni, és 61 százalékuk értette meg azt, hogy milyen hatása van az inflációnak a vásárlóerőparitásra. A válaszadók 67 százaléka tudta megfelelően osztályozni a befektetési kockázatokat. A válaszadók kevesebb mint egyharmada válaszolta meg helyesen azt a három kérdést, amelyet a pénzügyi tudatosság mérésére használnak. A társadalom bizonyos rétegei sokkal sérülékenyebbek, mint mások: a nők, a fiatal felnőttek, az idősek és a szerényebb képzettségü emberek (Arrondel, 2018).

Megközelítőleg 29 millió francia háztartás rendelkezik tekintélyes megtakarításokkal (a bruttó rendelkezésre álló jövedelem 16 százalékával). A megtakarítások nagyrésze azonban nem a leghatékonyabb csatornákba áramlik, ugyanis a megtakarítási eszközök között nagy szerepet játszanak az ingatlanok. A francia háztartások pénzügyi megtakarításai a bruttó rendelkezésre álló jövedelem közel 6 százalékát érik el, ami az eurózóna átlaga feletti érték (Arrondel et al., 2020).

A második világháború után a jóléti állam központi szerepet játszott a francia nyugdíjrendszerben. A vontatott gazdasági növekedés és a korstruktúra kedvezőtlen változása azonban megterhelte a francia felosztó-kirovó nyugdíjrendszert. 2050-re 60 százalékkal növekszik majd a nyugdíjas háztartások száma, ezen idő alatt pedig a munkaképes korú népesség alig 10 százalékkal. Ráadásul 2019-ben a nyugdíjrendszerhez köthető hiány 4,2 milliárd eurót ért el, amely azért is lehet meglepő, mert az utóbbi időszakban számos fontosabb reformintézkedés született. Az országban alapvetően historikusan magasak a megtakarítási ráták, így a legfontosabb kérdés az, hogyan alakulnak a családok portfólióinak elemei, és milyen lendületet vesz a vagyonfelhalmozás. Ebből adódóan a pénzügyi oktatás fontos szerepet kell, hogy vállaljon a pénzügyi portfólió megtervezésében és kockázatosságának kialakításában (Arrondel, 2018).

Franciaországban már évtizedekkel korábban elindult az általános iskolákban a takarékoskodásra való nevelés, és a takarékpénztárak már a hatvanas években is takarékoskodásra ösztönző képeskönyveket osztottak az alsósoknak, hogy segítsék az iskolai megtakarítást. Mint ahogyan más országokban is, az OECD Financial Literacy Programme bevezetésével Franciaországban is elindult a pénzügyi oktatás átfogó fejlesztése. Elsőként a Public Financial Literacy Institute (IEFP) jött létre 2006-ban, majd 2011-ben a Cité de l'Économie et de la Monnaie, később, 2017-ben pedig a Banque de France égisze alatt működő My Money matters 
program. A Banque de France (2019) szerint egyébként a franciák közgazdasági tudásának mérése már több mint húsz éve nagyobb hangsúlyt kap, és ezt gyakran megismételt felmérések is megerősítik.

Franciaországban a pénzügyi oktatás kapcsán nemzeti szintű stratégiát hoztak létre, melyben a pénzügyi szabályozó hatóság fontos szerepet játszik. Ugyanakkor az iskolákban nem kötelező a pénzügyi oktatás. A francia bankszövetség (French Banking Federation, FBF) legfontosabb célkitüzése a pénzügyi oktatás kapcsán az, hogy a francia rendszerhez köthető pénzügyi tudást adjon át. Az FBF olyan oktatási programot hozott létre, mint a Keys of the Banks, amely az önkéntesek és a szociális munkások szektorát érinti. Ingyenes információ és számos eszköz érhető el az állampolgárok számára a mindennapos bankolás könnyebb megértéséhez. Az egyszerű és magyarázó nyelvezet segítségével ez a teljesen ingyenes program a bankolás jobb megértését szolgálja. A kezdeményezés 2015-ben indult, és több mint 4 millió embernek segít minden évben.

$\mathrm{Az}$ ország bankszövetsége ugyancsak 2015-ben indította útjára az I invite a Banker to my Classrom kezdeményezést. Játékos oktatási tapasztalaton keresztül a program a 8-11 éves diákok számára a kezdeti költségvetési tervezés lehetőségét adja meg, amelyhez az iskolai oktatási program és a játékos oktatási workshopok adnak alapot. Amint keresni kezdenek, a diákok azonnal alkalmazhatják az elsajátított képességeket annak érdekében, hogy takarékoskodjanak, és érdemben kezeljék a kezdeti jövedelmüket. Az I Invite a Banker to my Classroom kezdeményezés 2019-ben 20 ezer diáknak segített, azonban az elkövetkező években a résztvevők száma várhatóan növekszik, ugyanis 2020-tól a Ministry of Education felügyeli a programot. Az FBF egy új pénzügyi oktatási kezdeményezésen is dolgozik, amely ahhoz a nemzeti univerzális szolgáltatáshoz kapcsolódik, amelyhez a francia jegybank és más érintettek is kapcsolódnak. Az alapötlet az, hogy a 16-18 éves önkéntesek számára vicces foglalkoztatási lehetőségeket biztosítsanak a költségvetés, a fizetések, a hitelek és a megtakarítások témakörében. A modulok szervezése a bankárok tevékeny részvételét igényli, és az eseményeket minden évben júniusban és júliusban tartják.

Az FBF tevékenyen részt vesz a francia jegybank által elindított pénzügyi oktatás nemzeti stratégiájának alakításában, amelyben a Ministry of Economy and Finance, a Ministry of National Education and Youth, a Ministry of Agriculture és a Ministry of Social Affairs is komoly szerepet vállal. A banki szektor szerepe fontos, a fogyasztói csoportosulásoknak is részt kell vállalniuk a kezdeményezések formálásában. Franciaországban az iskolák és a közösségi testületek üdvözlik a banki szektor segítségét a pénzügyi oktatásban. A döntéshozók pedig támogatják a bankszektor erőfeszítéseit. 


\subsection{Hollandia példája}

Hollandia a legmagasabb fejlettségi szintet elért országok közé tartozik az Európai Unióban, amit jól példáz, hogy kiterjedt társadalombiztosítási és nyugdíjrendszere van. Annak ellenére, hogy az utóbbi évtizedekben látványos növekedési ütemet tudott fenntartani az ország, és a jóléti társadalmak egyik mintaképe, a lakosságból mintegy 3 milliónyian a pénzügyileg sérülékeny csoportba tartoznak (MoneyWise, 2019). Ráadásul, ahogyan ezt az ország statisztikai hivatala is megerősíti, a holland háztartások több mint 13 százaléka felkészületlenül várja/ várná a pénzügyi viharokat (Statistics Netherlands [CBS], 2019). Meglepő továbbá azt látni, hogy azon háztartások száma, amelyek nehezen menedzselhető adósságokkal küzdenek, meredeken emelkedett az utóbbi években. Ez pedig különösen a fiatal családoknál jellemző, ugyanis a holland Debt Registration Center (BKR) 2020-as kimutatása szerint hét egyén közül egynek vannak pénzügyi gondjai, és ezek az egyének jellemzően 24 évnél fiatalabbak. A pénzügyi piacok a digitalizációs és egyéb tendenciáknak köszönhetően egyre összetettebbé válnak/ váltak, és a kormányok is egyre nagyobb mozgásteret adnak az egyének számára a saját pénzügyeik menedzselésében. Ennek fontos példáját mutatja a holland kormányzat azon lépése, hogy 2015-ben 2021-től 67 évre emelte a nyugdíjkorhatárt, és ennek a változását a születéskor várható élettartamhoz kötötte. Mindez pedig azt jelenti, hogy az egyéneknek maguknak kell meghatározniuk, hogy mennyit takarékoskodnak, ha korábban szeretnének nyugdíjba menni. Ezen kívül még számos olyan intézkedés született, mely egyértelmüen jelzi, hogy a hollandoknak nagyobb figyelemmel kell kísérniük saját pénzügyeiket.

A pénzügyi tudatosságra vonatkozóan egyébként a holland jegybank Household Survey felmérését emelhetjük ki elsőként 2010-ből, amelyen a megkérdezettek közel 45 százaléka felelt helyesen a pénzügyi tudatosság három nagy kérdésére. Lusardi és Mitchell (2014) azonban felhívja a figyelmünket arra a tényre, hogy a német $(53,2 \%)$ és a svájci $(50,1 \%)$ eredmények még ennél is jobbak voltak. A felmérést 2015-ben megismételték, amiből az derült ki, hogy a holland válaszadók 47,2 százaléka válaszolt helyesen, ez némi javulást mutat. Az OECD 2016-as kutatása szerint 21-től 13,4-es értéket ért el Hollandia, ami az akkor vizsgálat alá vont 30 ország esetében átlag feletti pontszámot jelentett, viszont az OECD-országoknál átlag alattit.

Ahogyan az már korábban kiemelésre került, a Standard \& Poor’s Global Financial Literacy Survey felmérése több mint 140 országra fókuszál. A szervezet öt kérést tesz fel, amelyek érintik a kockázatok diverzifikációját, az alapvető számolási készségeket, az inflációt és a kamatos kamatot. Ebben a felmérésben Hollandia a legmagasabb pénzügyi műveltséggel rendelkező országok között szerepelt, ugyanis a válaszadók 66 százaléka pénzügyi szempontból műveltnek volt tekinthető (Klapper et al., 2015). A felmérések alapján egyébként azt mondhatjuk, 
hogy a hollandok a pénzügyi müveltség tekintetében viszonylag jól teljesítenek. A holland fiatalok pénzügyi müveltsége nagyjából megegyezik a teljes népességével, azonban körülbelül ötből egy diáknak nincsenek meg az alapvető képességei ahhoz, hogy mindennapi pénzügyi döntéseket hozzon. Ráadásul a társadalmi és gazdasági szempontból hátrányos helyzetű fiatal válaszadók kétszer nagyobb valószínűséggel értek el alacsonyabb pénzügyi müveltségi mutatókat, mint az előnyösebb helyzetben lévők (OECD, 2017).

Hollandiában az első pénzügyi kultúra fejlesztését érintő nemzeti stratégia 2008ban indult, ezt 2014-ben és 2019-ben továbbfejlesztették. Ennek hivatalos neve a National Strategy for Financial Education. Hollandiában tehát nemzeti szintü stratégia müködik a pénzügyi oktatás területén, amit egyébiránt a magán- és az állami szereplők jó együttműködése fémjelez. A pénzügyekkel való foglalkozás kulcsfontosságú a tinédzserek számára, ugyanis számos középiskolás vállal félállást és kezd pénzt keresni, azonban a pénzügyi stúdiumok oktatása még mindig nem kötelező. A Holland Bankszövetség (Dutch Banking Association, DBA) különös figyelmet fordít a pénzügyi oktatásra, amelynek legfontosabb elemei a gyerekeket és a fiatalokat megcélzó pénzügyi müveltségi programok. A szervezet célja az, hogy pénzügyi készségekkel ruházza fel a fiatalokat. A DBA az állami és a magánkezdeményezések fó résztvevőjeként müködik közre a pénzügyi oktatási programokban, amely minden korosztályt igyekszik bevonni, és a sérülékeny csoportokra is fókuszál (Arrondel et al., 2020).

A Holland Bankszövetség 2011 óta szervezi meg a Bank in the Classroomot, az általános iskolások számára létrehozott oktatási programot. Minden évben egy izgalmas Cash Quizt rendeznek, amit egy, a pénzhez kapcsolódó játék követ. Banki alkalmazottak önkéntesként jelentkeznek kvízmesternek. 2021-től kezdődően a holland Money Week program és a Bank in the Classrom kezdeményezés teljesen átállt online formára az új típusú koronavírus-járvány miatt. A DBA másik oktatási programokat is elindított: Money Type Test, Me and my Money (ezek a középiskolák számára érhetők el). A How to earn money pedig a szakközépiskolákat célozza meg. Ezen túl érdemes még kiemelni, hogy a DBA részt vesz a European Money Quiz programban is, és 2019-ben nagyjából 200 ezer fiatal vett részt a bankszövetség által indított oktatási programokban.

Hollandiában a MoneyWise kezdeményezésben jelenik meg az állami szervek és az iparágak együttmüködése. Máxima királynő oroszlánrészt vállal továbbá a pénzügyi készségek fejlesztésében, ugyanis ő a MoneyWise platform tiszteletbeli elnöke. Az egyes kereskedelmi bankok részt vesznek a pénzügyi oktatási programokban, ráadásul saját projekteket is indítanak a pénzügyi oktatás területén. A fiatalok számára szervezett programokat támogatnak, segítik a költségvetés tervezését és információt szolgáltatnak pénzügyi kérdésekben a szélesebb közösség számára. 
Hollandia egyértelműen jó példáját mutatja az állami és a magánszereplök együttműködésének, aminek a koordinálásában a holland pénzügyminisztérium vesz részt. Ehhez illeszkedik, Magyarországhoz hasonlóan, számos olyan szervezet, amely a pénzügyi tudatosság fejlesztésében vesz részt. Ezek között az első a National Institute for Family Finance Information (NIBUD) volt, amely független alapítványként arra törekszik, hogy információt és tanácsot nyújtson a háztartásoknak pénzügyi kérdésekben. Emellett pedig az intézmény azoknak a szakembereknek is igyekszik segíteni, akik a fogyasztók pénzügyi kérdéseivel foglalkoznak (bankok, pénzügyi szolgáltató intézmények és tanárok). A NIBUD leginkább kutatásokkal, tanácsokkal, referenciaadatokkal, kalkulációs eszközökkel, oktatással és oktatási eszközökkel segít. Később, 2006-ban a holland pénzügyminisztérium elindította a MoneyWise platformot, amelynek célja az állampolgárok pénzügyi jóllétének a javítása volt. Jelenleg a legnagyobb hangsúlyt a pénzügyi oktatás terén az kapja, hogyan készítsék fel a háztartásokat és különösen a legsérülékenyebb csoportokat arra, hogy kezelni tudják a kiszámíthatatlan élethelyzeteket (munkahelyek elvesztése vagy éppen betegség), és pénzügyi szempontból csökkenjen a sérülékenységük. Emellett pedig az is nagy szerepet kap a MoneyWise kezdeményezésben, hogy ne csak fiatalkorban induljon el a pénzügyi készségek fejlesztése, hanem ezen készségek kialakítása a képzés minden szintjén váljon az iskolai oktatási programok szerves részévé. Az olyan pénzügyi intézmények, mint például a bankok vagy a biztosítótársaságok és nyugdíjalapok, az ügyfeleik oktatása segítségével igyekeznek előmozdítani a felelős pénzügyi döntések meghozatalát. Az egyik legnagyobb holland bank, az ING például elindította a Think Forward kezdeményezést, amellyel a pénzügyi döntések mögötti mechanizmusokat igyekszik megérteni, és a megszerzett tudást arra kívánja felhasználni, hogy olyan eszközöket fejlesszen ki, amelyekkel az egyének pénzügyi döntéseit segíthetik. Az egyértelmüen látható, hogy Hollandiában számos kezdeményezés indult el a pénzügyi tudatosság növelésére, de még mindig van lehetőség az elörelépésre.

A pénzügyi ismeretek egyébként választható tantárgy az iskolákban, és a közgazdaságtanhoz, a matematikához és a társadalomtudományokhoz kapcsolódóan oktatják. A pénzügyi ismeretek elsajátítása várhatóan a 2023/2024-es tanévtől kezdődően kötelezővé válik.

\subsection{Svájc példája}

Lusardi (2019) tanulmánya arra mutat rá, hogy a nagyjából 8 milliós népességü Svájcban Ausztriával és Németországgal egyetemben kimondottan magas a pénzügyi müveltség foka. Az ország azonban az alacsonyabb kategóriában tekinthető éllovasnak, ugyanis a megkérdezetteknek mindösszesen fele tudott érdemi és helyes választ adni a pénzügyi műveltség híres három kérdésére. Svájc illesz- 
kedik továbbá ahhoz a globális mintázathoz, hogy a pénzügyi kulturáltság foka nagy heterogenitást mutat a különböző társadalmi csoportok esetében. Alacsony mutatókat találhatunk az alacsony jövedelmü, kevésbé képzett háztartások esetében és azon családoknál, amelyek bevándorló hátterüek, és még nem beszélik anyanyelvi szinten a németet és a franciát. Ráadásul a nők is rendre alacsonyabb pontszámot érnek el. A fiatal felnőttek és iskoláskorúak eladósodottságát tekintve az állapítható meg, hogy az ország nem teljesít az átlag felett más korcsoportokkal vagy éppen más országokkal való összehasonlításban (Arrondel et al., 2020).

Ahogyan a korábbiakban láthattuk, számos országban nemzeti szintű stratégiát alkottak a pénzügyi oktatásra vonatkozóan, amelyekkel a területhez kapcsolódóan harmonizáció és koordináció történik. A nemzetközi folyamatokkal öszszehasonlítva, a Svájcban zajló folyamatok más képet mutatnak, és teljesen decentralizáltak. Ugyan egyre több olyan magán- és állami szereplő van, aki/amely pénzügyi témában kínál oktatási programokat az iskolák vagy éppen a szélesebb közönség számára, Svájcban azonban sem nemzeti stratégia, sem pedig kimondottan felelős hatóság nincs kijelölve az alapvető pénzügyi oktatás szervezésére. Az úgynevezett The franc in your pocket kivételével egészen kevés széles körü felmérés, iskolai kísérlet vagy kampány létezik. Ezen túl Svájc nem vesz részt a PISA-felmérés azon önkéntes kiegészítő részében, amelyet egyébiránt 2012-ben indítottak útjára, és a pénzügyi műveltséget hivatott mérni.

Az olyan föderalista, többnyelvű és demokratikus országok számára, mint Svájc nyilvánvalóan a nemzeti szintü, felülről vezérelt stratégia lehet a járható út úgy, hogy regionális és helyi szinten megfelelő nagyságú politikai autonómiát élvezzen. A pénzügyi oktatásnak Svájcban is, ahogyan más országokban is fontos szerepet kell kapnia, ugyanis a nyugdíjrendszerek finanszírozása egyre nagyobb kihívást jelent majd a kedvezőtlen demográfiai folyamatok tükrében. A negatív kamatlábak, vagy éppen az alacsony kamatlábak hosszú távú hatásai és az ebből következő, túlzott eladósodás iránti hajlandóság szintén aggodalomra adhat okot. Nyilvánvalóan fontos kérdés az új technológiák hatása a pénzügyi piacokra, a pénzügyi termékekre és szolgáltatásokra, valamint a fogyasztók viselkedésére. Mint ahogyan számos más országban, az új típusú koronavírus-járvány Svájcban is ráirányította a figyelmet, hogy a pénzügyi tudatosságnak kiemelt jelentősége van pénzügyi válságok idején - különösen a részfoglalkozásúak és az alacsony bérekből élők esetében (Arrondel et al., 2020).

Ugyan nincs nemzeti szintű pénzügyi oktatási stratégia Svájcban, a vonatkozó iskolai képzési programok mégis egészen jól lefedik a pénzügyi oktatást. A személyes pénzügyi kérdések nem feltétlenül kerülnek a középpontba, de alapvetően a széles körben elfogadott gazdasági oktatás részét képezik. Pénzügyi kérdéseket leginkább olyan tantárgyak körében feszegetnek, mint a gazdaságtan, háztartások és munkaerőpiac. A regionális tantervben vannak kötelező pézügyi témák 
iskolai szinten (a Lehrplan 21 a német nyelvü kantonok esetében, a d'Études roman a francia kantonok esetében és a Piano di studio Ticino kanton esetében). A Lehrplan 21 jelenti a legfontosabb részét a már említett gazdaságtan, háztartások és munkaerőpiac tantárgynak.

Ez idáig a Svájci Nemzeti Bank (Swiss National Bank, SNB) az egyetlen olyan nemzeti hatóság, amely módszeresen segíti a pénzügyi oktatást az országban. Mindezt azon Iconomix nevü oktatási program keretein belül teszi, amely a gazdasági és társadalomtudományi tanárokat szólítja meg, azonban más tanárok és más tantárgyak keretein belül is használhatják az egyébként választható tantárgyat. A program célja, hogy a fiatalok és a serdülőkorúak gazdasági és pénzügyi készségeit javítsa. A kezdeményezés 2007-es indulása óta a pénzügyi oktatás a fö fókuszba került. A jelenleg elérhető nagyjából 1oo oktatási modul fele közvetlenül kapcsolódik a pénzügyi kultúrához. A jegybank kezdeményezése mellett számos állami és magán pénzügyi szereplő kínál pénzügyi műveltséget előtérbe helyező programokat és szolgálatásokat. Ezek között találhatók helyi és regionális adósság- és költségvetési tanácsadó központok a saját ernyőszervezeteikkel együtt. Zürich városának van eladósodást megelőző központja, és léteznek olyan nonprofit szervezetek is, mint a Caritas, a Pro Juventute és a Verein Jugendlohn. A pénzügyi müveltséget kínáló szervezetek közé tartoznak a pénzügyi szektor profitorientált intézményei is. Ezek közül az állami Postfinance és a Cantonal Banks jelenleg a legaktívabbak. Ezekből a kezdeményezésekből jól látható, hogy Svájcban, más európai országok mintájára, szorosabb nemzeti koordinációra és együttműködésre lenne szükség. Az utóbbi időben egyértelmű erőfeszítések történtek a Swiss Money Week (SMW) elindítására, amely a Global Money Week-hez illeszkedne. A szereplők által megfogalmazott cél a pénzügyi műveltség népszerüsitése a svájci lakosság körében (Arrondel et al., 2020).

\section{4. ÖSSZEGZÉS ÉS LEHETÖSÉGEK, JAVASLATOK A PÉNZÜGYI TUDATOSSÁG TOVÁBBI JAVÍTÁSÁRA}

A tanulmány elsősorban arra kívánt összpontosítani, hogy a harmadik évezred elején különösen nagy figyelmet kapott pénzügyi oktatás milyen eredményeket hozott a világ régióiban és országaiban. Az összehasonlítás során látható volt, hogy Európa a pénzügyi tudatosság tekintetében a vezető világgazdasági régiók között szerepel, ami indokolttá teheti néhány ország kezdeményezéseinek, tapasztalatainak összefoglalását és a jó gyakorlatok megismerését. Annál is inkább, mert ahogyan röviden bemutattuk, a pénzügyi kulturáltság foka és a gazdasági növekedés között szoros együttmozgás figyelhető meg. Finnországban, Németországban, Franciaországban, Hollandiában és Svájcban nem minden esetben 
vezettek be nemzeti szintủ oktatási stratégiát, az azonban szinte mindenhol megfigyelhető, hogy nem egyetlen szereplő feladata a pénzügyi ismeretek terjesztése.

Az európai példákból láthattuk, hogy a pénzügyi műveltség növelése mindenhol egyértelmű cél, és leggyakrabban piaci és állami szereplők kapcsolódnak össze ahhoz, hogy ezt a lehető legjobban elősegítsék. Mindezt megerősíti Terták (2022) is, amikor felhívja a figyelmet arra, hogy a pénzügyi oktatás elengedhetetlen a fogyasztók pénzügyi biztonságának növeléséhez, ugyanakkor rávilágít arra, hogy indokolatlan lehet a pénzügyi oktatással kapcsolatban túlzottan nagy elvárásokat támasztani. Szerinte érdemes ugyanis figyelembe venni, hogy az oktatás egyénenként eltérő ismeretszinteket generál. Ráadásul azt is egyértelműen láthatjuk, hogy az országok többségében még nincs kötelező jellegű pénzügyi oktatás, hanem a pénzügyi tantárgyak leggyakrabban különböző kapcsolódó tantárgyakba vannak integrálva. Ennek tükrében és a nagyobb hatékonyság elérése érdekében javasolható, hogy jöjjön létre a pénzügyi műveltség előmozdításához kapcsolódó tárgyak kötelező jellegű oktatása, ez a lépés mindenképpen javítani tudná az általános pénzügyi műveltséget. Ezen kívül azt is láthatjuk továbbá, hogy a pénzügyi ismeretek oktatása leggyakrabban már az általános iskola alsó tagozatában megkezdődik, és a középiskola felső tagozatában is folytatódik. A pénzügyi kérdésekkel való ismerkedés a vizsgált országokban tehát már a legfogékonyabb korban elindul, és tudatos stratégia mentén zajlik. 


\section{HIVATKOZÁSOK}

Arrondel, L. - Haupt, M. - Mancebón, M. - Nicolini, G. - Wälti, M. - Wiersma, J. (2020): Financial Literacy in Western Europe. HAL Open Science. Paris School of Economics, Working Paper, No. 2021-37, https://halshs.archives-ouvertes.fr/halshs-03243830.

Arrondel, L. (2018): Financial literacy and asset behaviour: Poor education and zero for conduct. Comparative Economic Studies, 6o(1), 144-16o. https://doi.org/10.1057/s41294-018-0053-9

Batsaikhan, U. - Demertzis, M. (2018): Financial literacy and inclusive growth in the European Union. Bruegel, Policy Contribution, Issue No 8, 1-18, https://www.bruegel.org/wp-content/ uploads/2018/05/PC-08_2018.pdf.

EBF (2020): Financial Literacy Playbook for Europe. Brussels: European Banking Federation, https:// www.ebf.eu/wp-content/uploads/2020/11/EBF-Financial-Literacy-Playbook-for-Europe.pdf.

Klapper, L. - Lusardi, A. - VAn Oudheusden, P. (2015): Financial Literacy Around the World: Insights from the Standard \& Poor's Ratings Services Global Financial Literacy Survey. https:// responsiblefinanceforum.org/publications/financial-literacy-around-the-world-insights-fromthe-standard-poors-ratings-services-global-financial-literacy-survey/.

Kovács, L. - NAGY, E. (2022): A hazai pénzügyi kultúra fejlesztésének aktuális feladatai. Gazdaság és Pénzügy, 9(1), 2-19, https://doi.org/10.33926/GP.2022.1.1.

Lusardi, A. - Mitchell, O. (2011): Financial literacy around the world: An overview. Journal of Pension Economics \& Finance, 10(4), 497-508. http://doi.org/10.3386/w17107.

LUSARDI, A. (2019): Financial literacy and the need for financial education: Evidence and implications. Swiss Journal of Economics and Statistics, 155(1), https://doi.org/10.1186/s41937-019-0027-5

Lusardi, A. - Michaud, P. C. - Mitchell, O. S. (2017). Optimal financial knowledge and wealth inequality. Journal of Political Economy, 125(2), 431-477. https://doi.org/10.1086/690950.

MoneyWise (2019): National Strategy 2019: Working together for the financial fitness of Dutch citizens. https://www.wijzeringeldzaken.nl/bibliotheek-/media/Engels/english-directionmoneywise-2019.pdf.

OECD (2012): PISA Financial Literacy Assessment of Students, Organisation for Economic Cooperation and Development, Paris.

OECD (2016): OECD/INFE International survey of adult financial literacy competencies. Organisation for Economic Cooperation and Development, https:/www.oecd.org/daf/fin/financialeducation/OECD-INFE-International-Survey-of-Adult-Financial-Literacy-Competencies.pdf.

Phelps, E. S. (2017): La prospérité de masse (OJ.ECONOMIE). Paris: Odile Jacob.

Statistics Netherlands (2019): The Netherlands on the European scale 2019. https://longreads.cbs.nl/ european-scale-2019/

Terták, E. (2022): Pénzügyi oktatás a világban. Gazdaság és Pénzügy, 9(1), 20-49, https://doi. org/10.33926/GP.2O22.1.2. 